Article

\title{
Preparation and Application of Bioshell Calcium Oxide (BiSCaO) Nanoparticle-Dispersions with Bactericidal Activity
}

\author{
Yoko Sato ${ }^{1}{ }^{\circledR}$, Masayuki Ishihara ${ }^{1, *}$, Shingo Nakamura ${ }^{1}{ }^{\circledR}$, Koichi Fukuda $^{1}$, \\ Tomohiro Takayama ${ }^{2}$, Sumiyo Hiruma ${ }^{1}$, Kaoru Murakami ${ }^{2}$, Masanori Fujita ${ }^{3}$ (D) and \\ Hidetaka Yokoe ${ }^{2}$ \\ 1 Division of Biomedical Engineering, Research Institute, National Defense Medical College, 3-2 Namiki, \\ Tokorazawa, Saitama 359-8513, Japan; ysato@ndmc.ac.jp (Y.S.); snaka@ndmc.ac.jp (S.N.); \\ khf05707@nifty.com (K.F.); res337@ndmc.ac.jp (S.H.) \\ 2 Department of Oral and Maxillofacial Surgery, National Defense Medical College, 3-2 Namiki, Tokorozawa, \\ Saitama 359-8513, Japan; taka01@ndmc.ac.jp (T.T.); murakami@ndmc.ac.jp (K.M.); yokoe@ndmc.ac.jp (H.Y.) \\ 3 Division of Environmental Medicine, Research Institute, National Defense Medical College, 3-2 Namiki, \\ Tokorozawa, Saitama 359-1324, Japan; fujitama@ndmc.ac.jp \\ * Correspondence: ishihara@ndmc.ac.jp; Tel.: +81-429-95-1211 (ext. 2610)
}

Received: 23 August 2019; Accepted: 8 September 2019; Published: 19 September 2019

\begin{abstract}
Scallop-shell powder (SSP) heated at high temperature exhibits high $\mathrm{pH}$ and broad antimicrobial activity. Bioshell calcium oxide (BiSCaO) is an SSP composed mainly of calcium oxide. It is poorly water-soluble under alkaline conditions and the generated precipitate can plug spray nozzles. The aim of this study was to establish that $\mathrm{BiSCaO}$ dispersion caused no significant $\mathrm{CaO}$ loss and plugging of spray nozzles, and to evaluate its deodorization and microbicidal abilities and its ability to reduce the concentrations of $\mathrm{NO}_{2}{ }^{-}$and $\mathrm{NO}_{3}{ }^{-}$. BiSCaO dispersions were prepared by mixing various concentrations of $\mathrm{BiSCaO}$ suspension, while phosphate compounds such as $\mathrm{Na}_{3} \mathrm{PO}_{4}, \mathrm{Na}_{2} \mathrm{HPO}_{4}$ or $\mathrm{NaH}_{2} \mathrm{PO}_{4}$ and the $\mathrm{pH}$, average diameter, zeta potential, and form of the compounds with cryo-SEM were evaluated. We evaluated deodorization using tainted pork meat and microbicidal efficacy using contaminated suspension with normal bacterial flora. The concentration of $\mathrm{NO}_{2}{ }^{-}$and $\mathrm{NO}_{3}{ }^{-}$after mixing BiSCaO dispersion and pure water containing a high proportion of $\mathrm{NO}_{2}{ }^{-}$and $\mathrm{NO}_{3}{ }^{-}$were measured. $\mathrm{BiSCaO}$ dispersion formed with $\mathrm{Na}_{2} \mathrm{HPO}_{4}$, whose ratio to $\mathrm{BiSCaO}$ was $60 \%$, showed a high $\mathrm{pH}(>12)$, a small particle diameter $(>181 \mathrm{~nm})$ and was stable for seven days. The BiSCaO dispersion showed higher deodorization and microbicidal activities than SSP-Ca $(\mathrm{OH})_{2}$, which was mainly composed of $\mathrm{Ca}(\mathrm{OH})_{2}$. $\mathrm{BiSCaO}$, but not SSP-Ca $(\mathrm{OH})_{2}$, could reduce the concentration of $\mathrm{NO}_{2}{ }^{-}$and $\mathrm{NO}_{3}{ }^{-}$by more than $90 \%$ within $15 \mathrm{~min}$. We developed a stable $\mathrm{BiSCaO}$ dispersion, and it had high deodorization and microbicidal efficacy. These activities of $\mathrm{BiSCaO}$ might result from the high $\mathrm{pH}$ caused by $\mathrm{CaO}$ hydration and a reduction activity causing active radical species.
\end{abstract}

Keywords: scallop-shell powder; calcium oxides; dispersion; microbicidal activity; deodorization; cyro-SEM

\section{Introduction}

Various metal nanoparticles (MNPs) have been used in diverse fields, ranging from environmental remediation and biomedicine to catalysis, opt-electronic materials, and sensors [1,2]. MNPs comprising silver $[1,3,4]$, copper oxide $[1,2,5]$, zinc oxide [1,2,6], titanium oxide [2,7], and calcium oxide (CaO) $[8,9]$ have strong antimicrobial activity against most microorganisms, including bacteria, fungi, and viruses. $\mathrm{CaO}$ nanoparticles have been synthesized by solution combustion methods using $\mathrm{Ca}(\mathrm{NO})_{3}$ and 
$\mathrm{NH}_{2} \mathrm{CONH}_{2}$ dissolved in water $[10,11]$. The proposed mechanism underlying the cytotoxicity of MNPs is considered to be at least partially due to the induction of reactive oxygen species (ROS), resulting in oxidative stress [12-15].

Calcium oxide produced from limestone ( $\mathrm{LiMCaO})$ is an important inorganic compound used in various industries as, for example, an adsorbent, toxic-waste remediation agent, and an alkalization agent. However, $\mathrm{LiMCaO}$ contains harmful impurities and has a dangerously high heat of hydration $[16,17]$. In contrast, scallop shells are a readily available source of $\mathrm{CaO}$ and are used as a food additive, as well as in plastering and paving materials. However, most scallop shells are considered to be industrial waste, and the shells accumulate on the shores of harvesting districts in Japan, causing serious problems such as offensive odors and soil pollution due to harmful materials and heavy metals leaching from the shells [18]. Heated scallop shell powder (SSP) is well known to exhibit potent microbicidal activity [19]. For example, SSP heated above $1000{ }^{\circ} \mathrm{C}$ and then ground shows broad microbicidal action against various viruses [20], bacteria [18,19], heat-resistant bacterial spores [18,21], fungi [22], and biofilms [12,23,24]. In addition, this material has served as an additive to prolong the shelf life of food products $[19,24]$. $\mathrm{CaO}$ is easily converted to $\mathrm{Ca}(\mathrm{OH})_{2}$ by hydration with water. $\mathrm{CaO}$ hydration generates a base and is considered to be one of mechanisms for the disinfection action of heated-SSP. For example, the disinfection activity of the $\mathrm{CaO}$ hydration reaction towards both total viable cells (TC) and coliform bacteria (CF) was higher than that of $\mathrm{Ca}(\mathrm{OH})_{2}$ or $\mathrm{NaOH}$ solutions at the same $\mathrm{pH}[24,25]$. BiSCaO suspension $(0.2 \mathrm{wt} \%)$ has been applied for the cleansing of contaminated wooden and pig skin pieces to remove both $\mathrm{TC}$ and $\mathrm{CF}$, compared to the equivalent concentration of $\mathrm{HOCl}(\mathrm{pH}$ 6.5) and $\mathrm{NaClO}$ ( $\mathrm{pH}$ 9.5). $\mathrm{BiSCaO}$ suspension solution has higher disinfection activity than those of $\mathrm{HOCl}$ and $\mathrm{NaClO}$ in both TC and CF $[25,26]$. On the other hand, povidone-iodine and chlorhexidine gluconate have required more than 10-fold higher concentrations for the disinfection of $\mathrm{BiSCaO}[25,26]$. Thus, $\mathrm{BiSCaO}$ has great potential to apply in medical care and the food industry.

Slurries of heated SSP (particle diameter range: $60-900 \mathrm{~nm}$ ) are prepared by grinding shells heated to over $1100{ }^{\circ} \mathrm{C}$ in a wet bead-grinding mill [19] and suspending the powder in sterile saline. The main component of this heated shell powder slurry is calcium hydroxide (SSP-Ca $\left.(\mathrm{OH})_{2}\right)$. Similarly, most commercially available heated shell powder products used as food additives are composed of $\mathrm{Ca}(\mathrm{OH})_{2}$. We used commercially available bioshell calcium oxide (BiSCaO, Plus Lab Co. Ltd., Kanagawa, Japan) in this study. According to the product instructions, $\mathrm{BiSCaO}$ contains over $99.6 \% \mathrm{CaO}$.

$\mathrm{BiSCaO}$ is poorly water-soluble under strongly alkaline conditions $(\mathrm{pH}>12)$. Water suspensions of high concentrations of $\mathrm{BiSCaO}$ can result in a significant loss of $\mathrm{CaO}$ during handling and can plug spray nozzles $[25,27]$. Therefore, it is necessary to prepare dispersions containing stabilized $\mathrm{CaO}$ nanoparticles. Various concentrations of $\mathrm{BiSCaO}$ dispersions containing $\mathrm{CaO} N \mathrm{Ns}(160-300 \mathrm{~nm})$ have been prepared by mixing $\mathrm{BiSCaO}$ with phosphate compounds such as $\mathrm{Na}_{3} \mathrm{PO}_{4}, \mathrm{Na}_{2} \mathrm{HPO}_{4}$, or $\mathrm{NaH}_{2} \mathrm{PO}_{4}$. In this study, we established conditions for generating $\mathrm{BiSCaO}$ dispersions using phosphoric acid and phosphate compounds by optimizing $\mathrm{pH}$, particle form, particle size, and zeta potential. We then studied the deodorizing and disinfecting effects of the resulting $\mathrm{BiSCaO}$ dispersions and their $\mathrm{NO}_{2} / \mathrm{NO}_{3}$ reducing activity.

\section{Results}

\subsection{BiSCaO Dispersion and Suspension with $\mathrm{H}_{3} \mathrm{PO}_{4}, \mathrm{Na}_{3} \mathrm{PO}_{4}, \mathrm{Na}_{2} \mathrm{HPO}_{4}$, and $\mathrm{NaH}_{2} \mathrm{PO}_{4}$}

Various amounts of phosphoric acid $\left(\mathrm{H}_{3} \mathrm{PO}_{4}\right)$, hydrochloric acid $(\mathrm{HCl})$, or sulfuric acid $\left(\mathrm{H}_{2} \mathrm{SO}_{4}\right)$ were added to suspensions of heated SSP with an average particle diameter of $6 \mu \mathrm{m}(\mathrm{BiSCaO}-6)$ to adjust the $\mathrm{pH}$. The results are shown in Figure 1 and Table 1. When adding $1 \mathrm{~N} \mathrm{H}_{3} \mathrm{PO}_{4}$ to $0.2 \mathrm{wt} \%$ BiSCaO-6 suspension, the $\mathrm{pH}$ changed from 12.53 to 12 and dispersion without any precipitate was formed. The dispersion was stable without generating any flocculent and precipitation for at least seven days. Flocculation was formed from $\mathrm{pH} 10.5$ to $\mathrm{pH}$ 6, and the flocculent completely dissolved to provide a clear solution at $\mathrm{pH} \leq 5$ (data not shown). In contrast, the addition of $\mathrm{HCl}$ or $\mathrm{H}_{2} \mathrm{SO}_{4}$ (Table 1) 
to $0.2 \mathrm{wt} \%$ BiSCaO-6 suspension generated neither a dispersion nor a flocculent. The precipitations were still formed at $\mathrm{pH} 12$; however, they completely dissolved to provide clear solutions when the $\mathrm{pH}$ was lowered to $\mathrm{pH} \leq 10.5$.

(a)

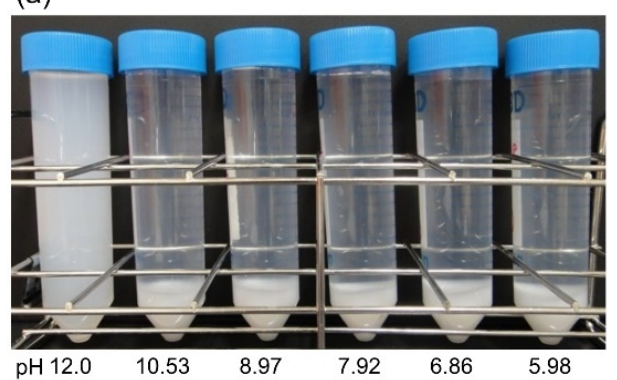

(b)

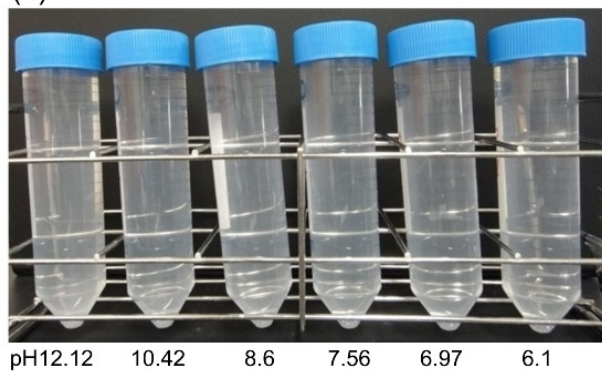

Figure 1. Addition to $\mathrm{H}_{3} \mathrm{PO}_{4}, \mathrm{HCl}$ to BiSCaO-6 suspension. Various amounts of $\mathrm{H}_{3} \mathrm{PO}_{4}(\mathbf{a})$ or $\mathrm{HCl}(\mathbf{b})$ were added to $2000 \mathrm{ppm}(0.2 \mathrm{wt} \%)$ BiSCaO- 6 water suspensions to adjust the $\mathrm{pH}$ to around 6, 7, 8, 9, 10.5 , and 12 .

Table 1. Changes in BiSCaO-6 suspensions by the addition of $\mathrm{H}_{3} \mathrm{PO}_{4}, \mathrm{HCl}, \mathrm{or}_{2} \mathrm{SO}_{4}$.

\begin{tabular}{|c|c|c|c|c|c|c|c|c|}
\hline \multirow[t]{3}{*}{$\mathrm{H} 3 \mathrm{PO} 4$} & $\mathrm{pH}$ & 12.53 & 12 & 10.53 & 8.97 & 7.92 & 6.86 & 5.98 \\
\hline & Dispersion (\%) & 0 & 100 & 0 & 0 & 0 & 0 & 0 \\
\hline & Flocculation (\%) & 0 & 0 & 20 & 17 & 16 & 15 & 15 \\
\hline \multirow{2}{*}{$\mathrm{HCl}$} & $\begin{array}{c}\text { Dispersion or } \\
\text { Flocculation (\%) }\end{array}$ & 0 & 0 & 0 & 0 & 0 & 0 & 0 \\
\hline & Form & $\begin{array}{c}\text { Only } \\
\text { precipitation }\end{array}$ & $\begin{array}{c}\text { Only } \\
\text { precipitation }\end{array}$ & Solution & Solution & Solution & Solution & Solution \\
\hline $\mathrm{H} 2 \mathrm{SO} 4$ & $\mathrm{pH}$ & 12.53 & 12 & 10.42 & 8.97 & 7.95 & 6.89 & 5.95 \\
\hline
\end{tabular}

The ratio of the layer of dispersion or flocculation to the total amount.

Next, various amounts of $\mathrm{Na}_{3} \mathrm{PO}_{4}$ (Table 2), $\mathrm{Na}_{2} \mathrm{HPO}_{4}$, or $\mathrm{NaH}_{2} \mathrm{PO}_{4}$ (Figure 2, Table 2) were added to $0.2 \mathrm{wt} \%$ BiSCaO- 6 suspension. Adding $0.28 \mathrm{wt} \% \mathrm{Na}_{3} \mathrm{PO}_{4}, \mathrm{Na}_{2} \mathrm{HPO}_{4}$, or $\mathrm{NaH}_{2} \mathrm{PO}_{4}$ resulted in formation of flocculation, and adding $0.2 \mathrm{wt} \%$ still caused slight flocculation. On the other hand, adding $0.12 \mathrm{wt} \% \mathrm{Na}_{3} \mathrm{PO}_{4}, \mathrm{Na}_{2} \mathrm{HPO}_{4}$, or $\mathrm{NaH}_{2} \mathrm{PO}_{4}$ resulted in dispersion without any precipitates and flocculates. Those dispersions were maintained for at least seven days.

(a)

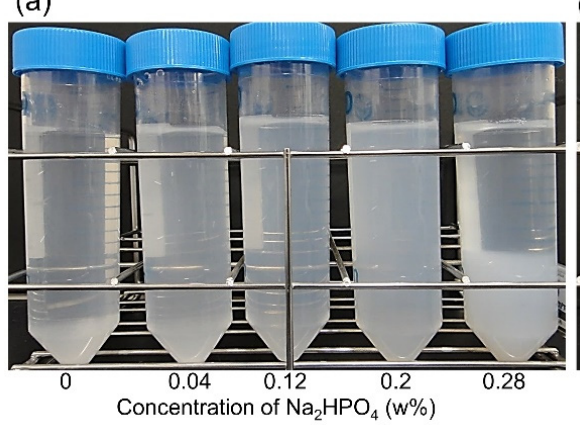

(b)

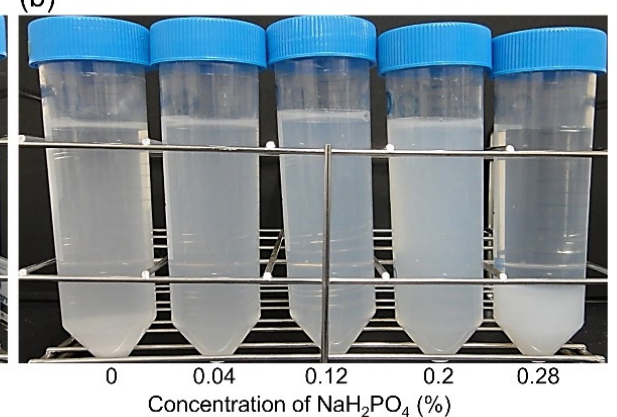

Figure 2. Formation of BiSCaO-6 dispersions and flocculants by the addition of $\mathrm{Na}_{2} \mathrm{HPO}_{4}$ or $\mathrm{NaH}_{2} \mathrm{PO}_{4}$. $0.04 \mathrm{wt} \%, 0.12 \mathrm{wt} \%, 0.2 \mathrm{wt} \%$, and $0.28 \mathrm{wt} \%$ of $\mathrm{Na}_{2} \mathrm{HPO}_{4}(\mathbf{a})$ and $\mathrm{NaH}_{2} \mathrm{PO}_{4}$ (b) were added to $0.2 \mathrm{wt} \%$ BisCaO-6 suspension and rotary mixed. 
Table 2. Changes in BiSCaO-6 water suspensions by the addition of $\mathrm{Na}_{3} \mathrm{PO}_{4}, \mathrm{Na}_{2} \mathrm{HPO}_{4}$, or $\mathrm{NaH}_{2} \mathrm{PO}_{4}$.

\begin{tabular}{ccccccc}
\hline \multirow{2}{*}{$\mathrm{Na}_{3} \mathrm{PO}_{4}$} & $\mathbf{0}$ & $\mathbf{0 . 0 4}$ & $\mathbf{0 . 1 2}$ & $\mathbf{0 . 2}$ & $\mathbf{0 . 2 8}$ \\
\cline { 2 - 7 } & $\begin{array}{c}\text { Layer sepa-ration } \\
\text { with flocculation (\%) }\end{array}$ & 0 & 12.55 & 12.55 & 12.25 & 12.1 \\
\cline { 2 - 7 } & Form & $\begin{array}{c}\text { Only } \\
\text { precipitation }\end{array}$ & $\begin{array}{c}\text { Dispersion with } \\
\text { precipitation }\end{array}$ & Dispersion & $\begin{array}{c}\text { Dispersion with } \\
\text { flocculation }\end{array}$ & $\begin{array}{c}\text { Only } \\
\text { flocculation }\end{array}$ \\
\hline $\mathrm{Na}_{2} \mathrm{HPO}_{4}$ & $\mathrm{pH}$ & 12.55 & 12.53 & 12.5 & 12 & 11.95 \\
\cline { 2 - 7 } & $\begin{array}{c}\text { Layer sepa-ration } \\
\text { with flocculation (\%) }\end{array}$ & 0 & 0 & 0 & 3 & 18 \\
\cline { 2 - 7 } & Form & $\begin{array}{c}\text { Only } \\
\text { precipitation }\end{array}$ & $\begin{array}{c}\text { Dispersion with } \\
\text { precipitation }\end{array}$ & Dispersion & $\begin{array}{c}\text { Dispersion with } \\
\text { flocculation }\end{array}$ & $\begin{array}{c}\text { Only } \\
\text { flocculation }\end{array}$ \\
\hline $\mathrm{NaH}_{2} \mathrm{PO}_{4}$ & $\begin{array}{c}\text { Layer sepa-ration } \\
\text { with flocculation (\%) }\end{array}$ & 0 & 12.55 & 12.49 & 12.05 & 11.65 \\
\cline { 2 - 7 } & Form & $\begin{array}{c}\text { Only } \\
\text { precipitation }\end{array}$ & $\begin{array}{c}\text { Dispersion with } \\
\text { precipitation }\end{array}$ & Dispersion & $\begin{array}{c}\text { Dispersion with } \\
\text { flocculation }\end{array}$ & $\begin{array}{c}\text { Only } \\
\text { flocculation }\end{array}$ \\
\hline
\end{tabular}

The ratio of the layer of dispersion or flocculation to total amount.

2.2. SEM Image of Dry BiSCaO-6 Powder and Nanoparticles in BiSCaO-6 Dispersions Formed by Adding $\mathrm{H}_{3} \mathrm{PO}_{4}, \mathrm{Na}_{3} \mathrm{PO}_{4}, \mathrm{Na}_{2} \mathrm{HPO}_{4}$, or $\mathrm{NaH}_{2} \mathrm{PO}_{4}$

The addition of $\mathrm{H}_{3} \mathrm{PO}_{4}$ (to $\mathrm{pH} 12$ ), or $0.12 \mathrm{wt} \% \mathrm{Na}_{3} \mathrm{PO}_{4}, \mathrm{Na}_{2} \mathrm{HPO}_{4}$, and $\mathrm{NaH}_{2} \mathrm{PO}_{4}$ to a 0.2 $\mathrm{w} \mathrm{t} \% \mathrm{BiSCaO}-6$ or $\mathrm{BiSCaO}$ (seven days) suspension resulted in a dispersion without precipitates and flocculates, the average particle diameter was $160-220 \mathrm{~nm}$, and the zeta potential was in the range +33.6 to +35.9 one day after adjustment (Table 3). Those dispersions remained stable for at least seven days in terms of $\mathrm{pH}$, average diameter, zeta potential, and phase form.

Table 3. Average diameter and zeta-potential of BiSCaO-6 particles in BiSCaO dispersions.

\begin{tabular}{|c|c|c|c|c|c|c|}
\hline & & \multicolumn{5}{|c|}{ Additive } \\
\hline & & Pure Water & $\mathrm{H}_{3} \mathrm{PO}_{4}$ & $\mathrm{Na}_{3} \mathrm{PO}_{4}$ & $\mathrm{Na}_{2} \mathrm{HPO}_{4}$ & $\mathrm{NaH}_{2} \mathrm{PO}_{4}$ \\
\hline \multirow[t]{4}{*}{$\begin{array}{l}\mathrm{BiSCaO}-6 \\
(0.2 \mathrm{wt} \%)\end{array}$} & $\mathrm{pH}$ & 12.5 & 12 & 12.55 & 12.5 & 12.45 \\
\hline & $\begin{array}{l}\text { Average diameter } \\
\text { in dispersion }(\mathrm{nm})\end{array}$ & 1060 (Supernatant) & 160 & 200 & 181 & 190 \\
\hline & Zeta potential & +29.1 & +35.9 & +35.6 & +33.6 & +35.8 \\
\hline & Phase form & Suspension with precipitation & \multicolumn{4}{|c|}{ Dispersion } \\
\hline \multirow{4}{*}{$\begin{array}{c}\text { BiSCaO-6 } \\
\text { (seven days) } \\
(0.2 \text { wt } \%)\end{array}$} & $\mathrm{pH}$ & 12.2 & 12 & 12.24 & 12.22 & 12.20 \\
\hline & $\begin{array}{l}\text { Average diameter } \\
\text { in dispersion }(\mathrm{nm})\end{array}$ & 610 (Supernatant) & 190 & 200 & 220 & 210 \\
\hline & Zeta potential & +29.0 & +33.8 & +33.9 & +34.1 & +33.6 \\
\hline & Phase form & Suspension with precipitation & \multicolumn{4}{|c|}{ Dispersion } \\
\hline
\end{tabular}

We present the SEM images of BiSCaO-6 dry powder and dispersion adjusted with $0.2 \mathrm{wt} \%$ BiSCaO-6 and $0.12 \mathrm{wt} \% \mathrm{Na}_{2} \mathrm{HPO}_{4}$ in Figure 3. BiSCaO-6 immediately after opening is a polymorphic powder with a wrinkled surface structure (Figure 3a), while BiSCaO-6 placed under high humidity at $37^{\circ} \mathrm{C}$ for seven days to prepare BiSCaO-6 (seven days) exhibited a porous surface structure similar to that of nanoparticle aggregates (Figure $3 b$ ). Those observations suggested that hydration reaction on the surface of BiSCaO-6 may lead to the refinement of $\mathrm{CaO}$ crystals and rift and pore formations, which may promote the production of nanoparticles from microparticles in water dispersion. Indeed, Figure $3 c$,d indicated that $\mathrm{CaO}$ particles in $\mathrm{BiSCaO}-6$ dispersion were nano scales. 
(a)

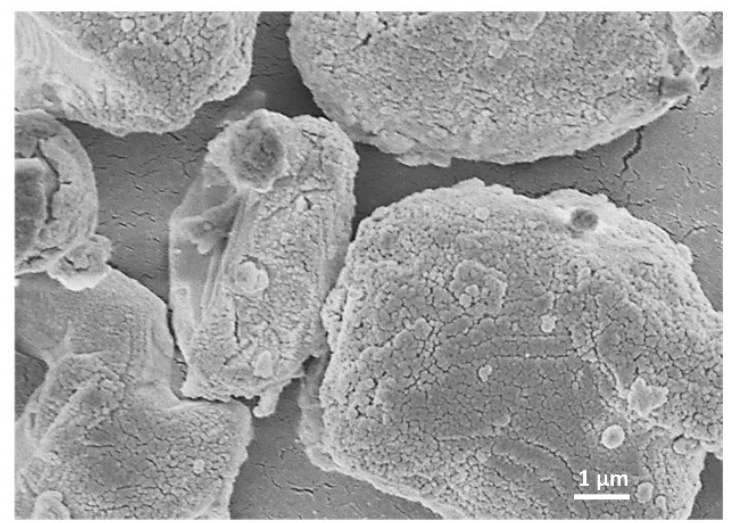

(c)

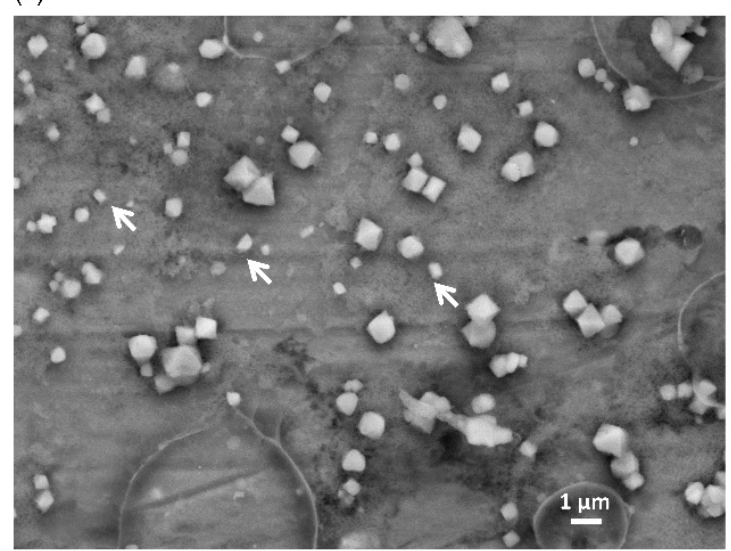

(b)

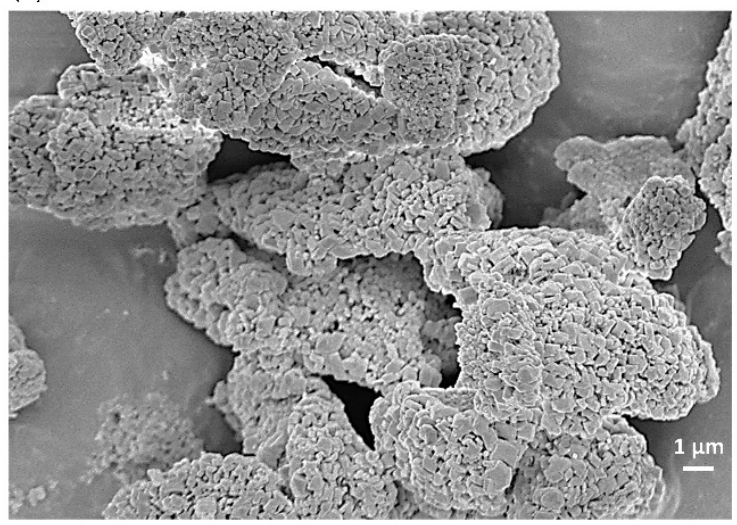

(d)

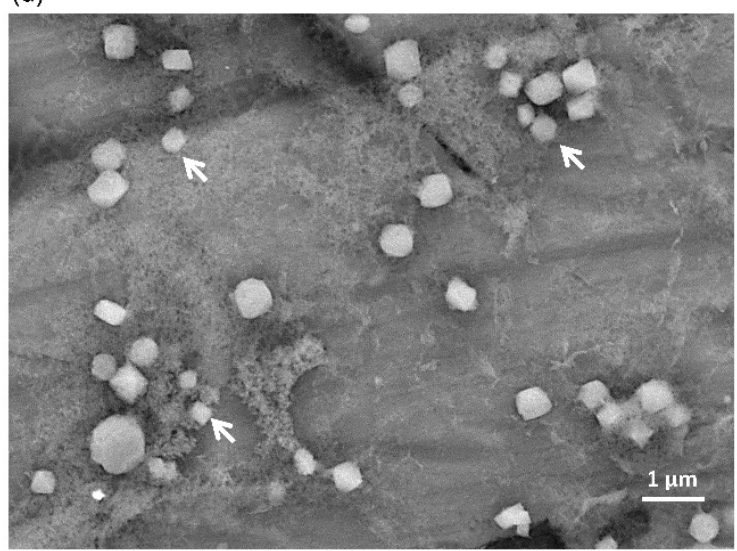

Figure 3. SEM images of BiSCaO-6 dry powder and dispersion. The surface structure of each dry powder of BiSCaO-6 immediately after opening at 10,000-fold magnification (a) and BiSCaO- 6 placed under high humidity at $37^{\circ} \mathrm{C}$ for seven days at 5000-fold magnification (b) were observed with SEM images of a field-resolved scanning electron microscope. Cryo-SEM observations were performed on BiSCaO-6 dispersions (0.2 wt $\%$ BiSCaO-6, $0.12 \mathrm{wt} \% \mathrm{Na}_{2} \mathrm{HPO}_{4}$ ) two days after adjustment at 5000 -fold magnification (c) and 10,000-fold magnification (d). Allows indicate nano particles.

\subsection{Deodorization of Contaminated Minced Pork by BiSCaO Dispersions}

We evaluated the deodorization efficacy of $\mathrm{BiSCaO}$ suspension and dispersion using tainted pork meat as a malodorous material. BiSCaO-6, BiSCaO-2000, and SSP-Ca $(\mathrm{OH})_{2}$ suspensions $(0.04 \mathrm{wt} \%$, $0.2 \mathrm{wt} \%$, and $1.0 \mathrm{wt} \%$ ) were prepared. We chose $\mathrm{Na}_{2} \mathrm{HPO}_{4}$ as an additive to form dispersion because of the generation of smaller particles and added $\mathrm{Na}_{2} \mathrm{HPO}_{4}$ to each suspension. The ratio of $\mathrm{Na}_{2} \mathrm{HPO}_{4}$ to $\mathrm{BiSCaO}$ and SSP-Ca(OH $)_{2}$ was $60 \%$. We examined suspensions and dispersions immediately after adjustment (/0), one day after adjustment (/1), and three days after adjustment (/3), as shown in Figure 4 . Tainted pork meat was mixed with each suspension or dispersion, then placed on a Petri dish and sealed in a plastic bag for $1 \mathrm{~h}$. The odor intensity was then measured using a handheld odor meter.

$\mathrm{BiSCaO}-6 / 0$ dispersion had the highest deodorization efficacy at each concentration tested and BiSCaO-6/1 and BiSCaO-6/3 dispersions were less efficient (Figure 4). A similar daily reduction for 0-3 days of deodorization efficacy by BiSCaO-2000/0 dispersion was observed (data not shown). In addition, $\mathrm{SSP}-\mathrm{Ca}(\mathrm{OH})_{2}$ dispersion had a lower deodorization efficacy than $\mathrm{BiSCaO}$ dispersion. 


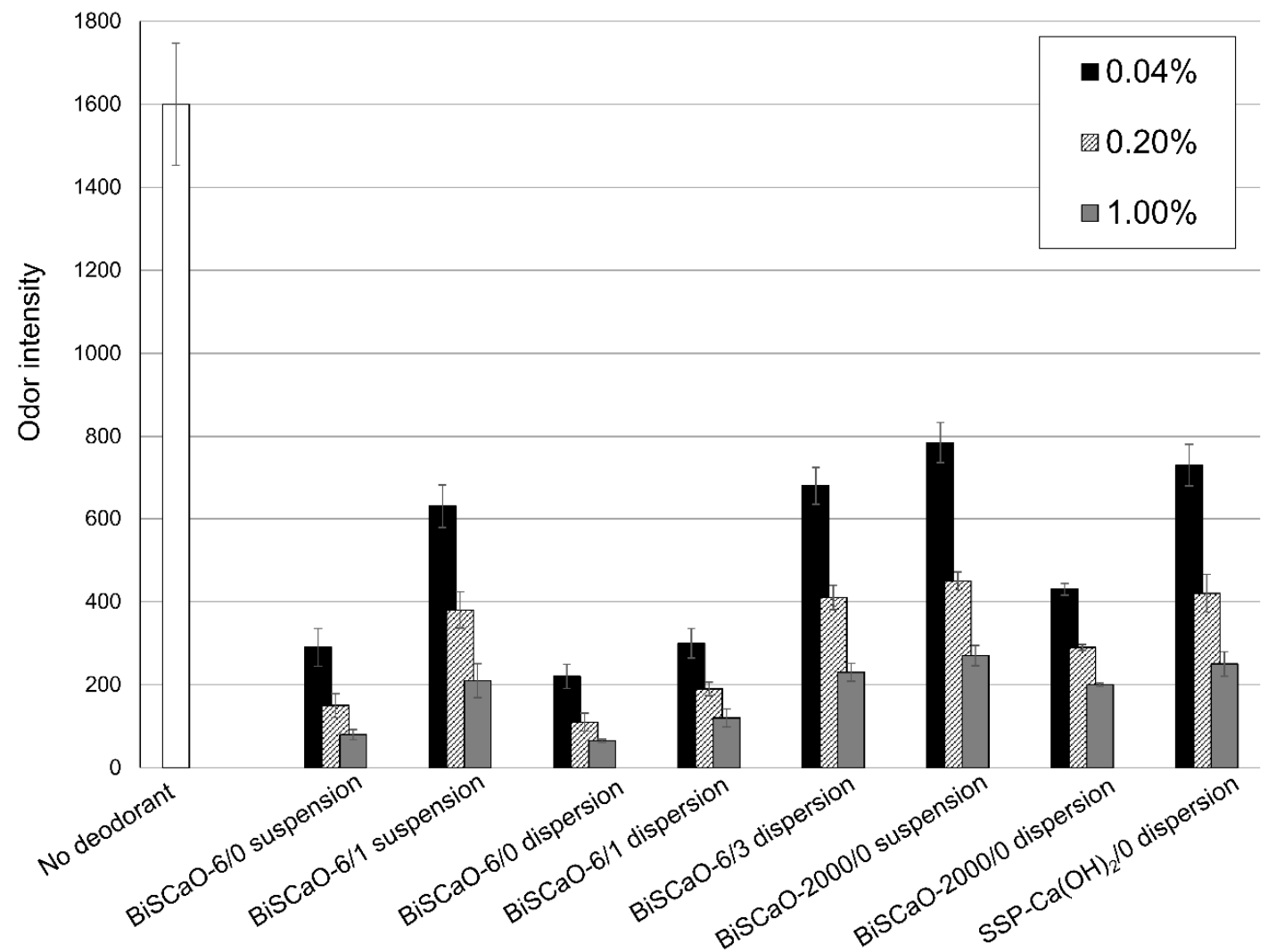

Figure 4. Efficacy of BiSCaO suspensions and dispersions for deodorizing contaminated minced pork. The indicated concentration and time after adjustment (/0: immediately after adjustment, /1: one day after adjustment, /3: three days after adjustment) of each BiSCaO suspension or dispersion was added to tainted pork meat on a petri dish, then sealed in a plastic bag for $1 \mathrm{~h}$. The odor intensity was then measured using a handheld odor meter. The experiments were repeated three times and all provided results identical to the results shown.

\subsection{Microbicidal Efficacy of BiSCaO Dispersions}

We investigated the microbicidal efficacy of $\mathrm{BiSCaO}$ and $\mathrm{SSP}-\mathrm{Ca}(\mathrm{OH})_{2}$ dispersions. A contaminated suspension with normal bacterial flora (total viable cells (TC) and coliform bacteria (CF)) was prepared by incubating remaining water in bathtub with $10 \%$ Dulbecco's modified Eagle's medium (DMEM) at $37^{\circ} \mathrm{C}$ for $24 \mathrm{~h}[15,27]$. In this incubation, the TC and CF cell count in the contaminated suspension increased from $100 \pm 45$ and $65 \pm 30$ to $6.8 \pm 1.5\left(\times 10^{8}\right) \mathrm{CFU} / \mathrm{mL}$ and $6.6 \pm 1.8\left(\times 10^{7}\right) \mathrm{CFU} / \mathrm{mL}$, respectively. After preparing the following concentrations of $1200(0.12 \mathrm{wt} \%), 400(0.04 \mathrm{wt} \%), 133(0.0133 \mathrm{wt} \%)$, and $44(0.0044 \mathrm{wt} \%)$ ppm BiSCaO and SSP-Ca $(\mathrm{OH})_{2}$ suspensions, dispersions were formed by adding $60 \% \mathrm{Na}_{2} \mathrm{HPO}_{4}$ to $\mathrm{BisCaO}$ or SSP-Ca(OH $)_{2}$ to each suspension. We examined dispersions immediately after adjustment (-/0), one day after adjustment (/1), and three days after adjustment (/3) as shown in Figure 4. Equal amounts of a dispersion and the contaminated suspension were mixed well and incubated at room temperature for $15 \mathrm{~min}$; then, the number of colony-forming units $(\mathrm{CFU} / \mathrm{mL})$ per sample was determined. The $\mathrm{CFU} / \mathrm{mL}$ of $600 \mathrm{ppm}$ BiSCaO-6/0 dispersion was not detectable in both TC and CF, whereas some TC and CF remained viable at 200 ppm or lower BiSCaO-6/0 dispersion (Figure 4). $\mathrm{BiSCaO} / 1$ and $\mathrm{BiSCaO} / 3$ dispersions had lower microbicidal activities at all concentrations than $\mathrm{BiSCaO} / 0$ dispersion (Figure 4). SSP-Ca $(\mathrm{OH})_{2}$ dispersion had lower microbicidal activity than $\mathrm{BiSCaO}$ dispersion at any concentrations. 


\subsection{Reduction of Aqueous $\mathrm{NO}_{2}$ and $\mathrm{NO}_{3}$ by $\mathrm{BiSCaO}$}

We studied the reduction in concentration of $\mathrm{NO}_{3}{ }^{-}$and $\mathrm{NO}_{2}{ }^{-}$by $\mathrm{BiSCaO}$. The addition of $0.2 \mathrm{wt} \% \mathrm{BiSCaO}-6, \mathrm{BiSCaO}-2000$ or $\mathrm{LiMCaO}$ powders to pure water containing $\mathrm{NO}_{2}{ }^{-}(1.8 \mathrm{ppm})$ and $\mathrm{NO}_{3}{ }^{-}(30 \mathrm{ppm})$ resulted in more than a $90 \%$ reduction of both $\mathrm{NO}_{2}{ }^{-}$and $\mathrm{NO}_{3}{ }^{-}$at room temperature within 15 min (Figure 5a,b). On the other hand, SSP-Ca(OH $)_{2}$ and $\mathrm{LiMCa}(\mathrm{OH})_{2}$ ) did not reduce $\mathrm{NO}_{2}{ }^{-}$ or $\mathrm{NO}_{3}{ }^{-}$concentrations over a period of $20 \mathrm{~h}$. We incubated BiSCaO-6 and BiSCaO-2000 powders at $37^{\circ} \mathrm{C}$ in the absence of desiccant for seven days before adding them to pure water containing $\mathrm{NO}_{2}{ }^{-}$ and $\mathrm{NO}_{3}{ }^{-}$. BiSCaO-6 (seven days) and BiSCaO-2000 (seven days) mildly reduced $\mathrm{NO}_{2}{ }^{-}$by half over a period of 1 and $3 \mathrm{~h}$, and reduced $\mathrm{NO}_{3}{ }^{-}$by half over a period of 3 and $5 \mathrm{~h}$, respectively.

Each $\mathrm{BiSCaO}$ and $\mathrm{LiMCaO}$ powder $(0.4 \mathrm{wt} \%)$ was hydrated in pure water during several time periods, then added to pure water containing $\mathrm{NO}_{2}{ }^{-}$and $\mathrm{NO}_{3}{ }^{-}$and mixed. The mixture was incubated at room temperature for $1 \mathrm{~h}$ and the measured concentration of $\mathrm{NO}_{2}{ }^{-}$and $\mathrm{NO}_{3}{ }^{-}$. BiSCaO-6, BiSCaO-12, BiSCaO-2000, and LiMCaO reduced the concentrations of both $\mathrm{NO}_{2}{ }^{-}$and $\mathrm{NO}_{3}{ }^{-}$by half in 1, 3, 4, and $5 \mathrm{~h}$ of hydration, respectively (Figure $6 \mathrm{c}, \mathrm{d}$ ). Their reducing activity decreased with hydration time. On the other hand, SSP-Ca $(\mathrm{OH})_{2}$ and $\mathrm{LiMCa}(\mathrm{OH})_{2}$ exhibited no reducing activity throughout the experiment.

(a)

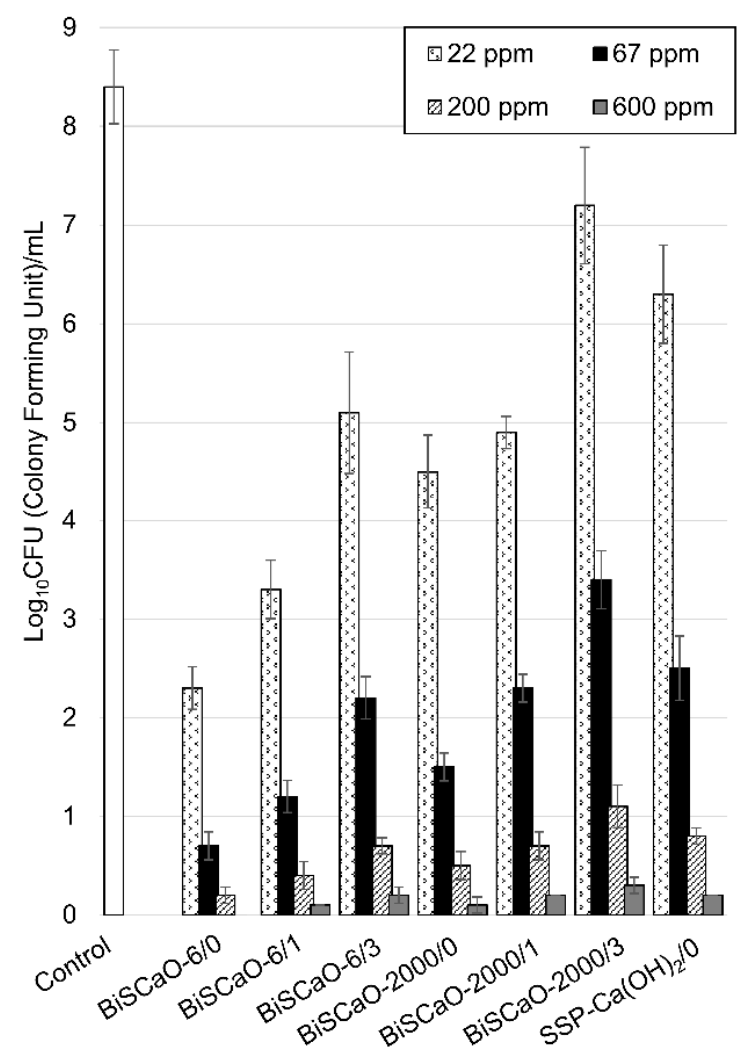

(b)

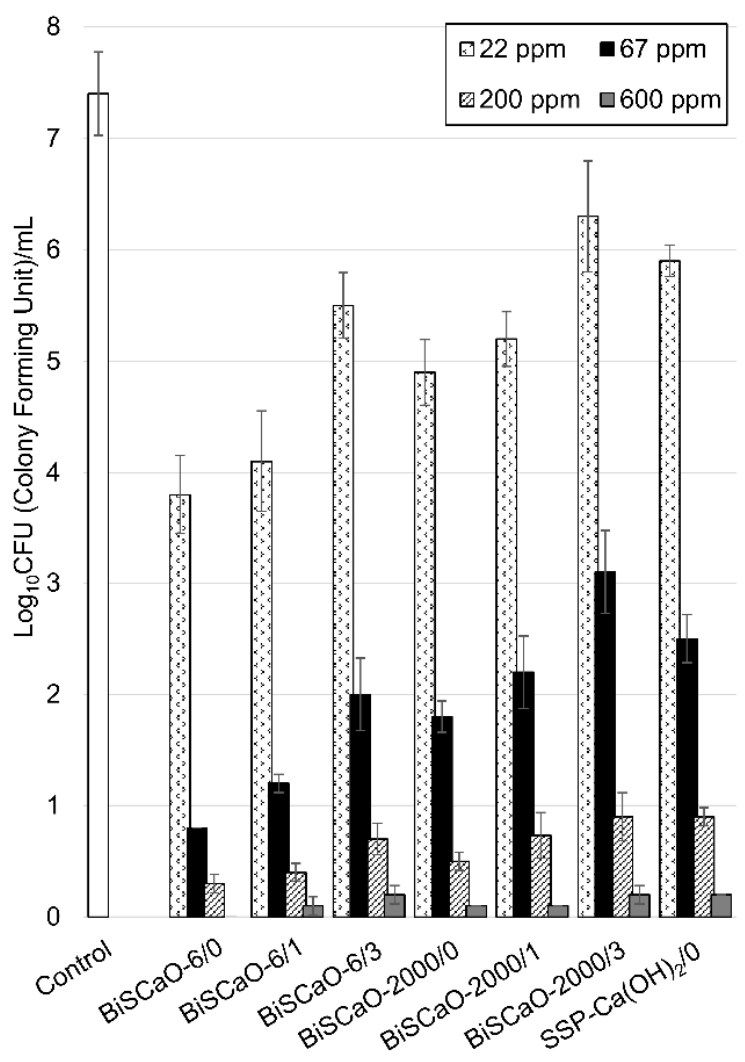

Figure 5. Microbicidal efficacy of BiSCaO dispersion. The number of colony forming units (CFUs) of (a) total viable microbe counts (TC) and (b) coliform bacteria (CF) in the contaminated suspension mixed with each BiSCaO were counted after gentle vortexing three times for $30 \mathrm{~s}$ and incubated at room temperature for $15 \mathrm{~min}(n=4)$. Pure water as control of disinfectant was used as the control. 

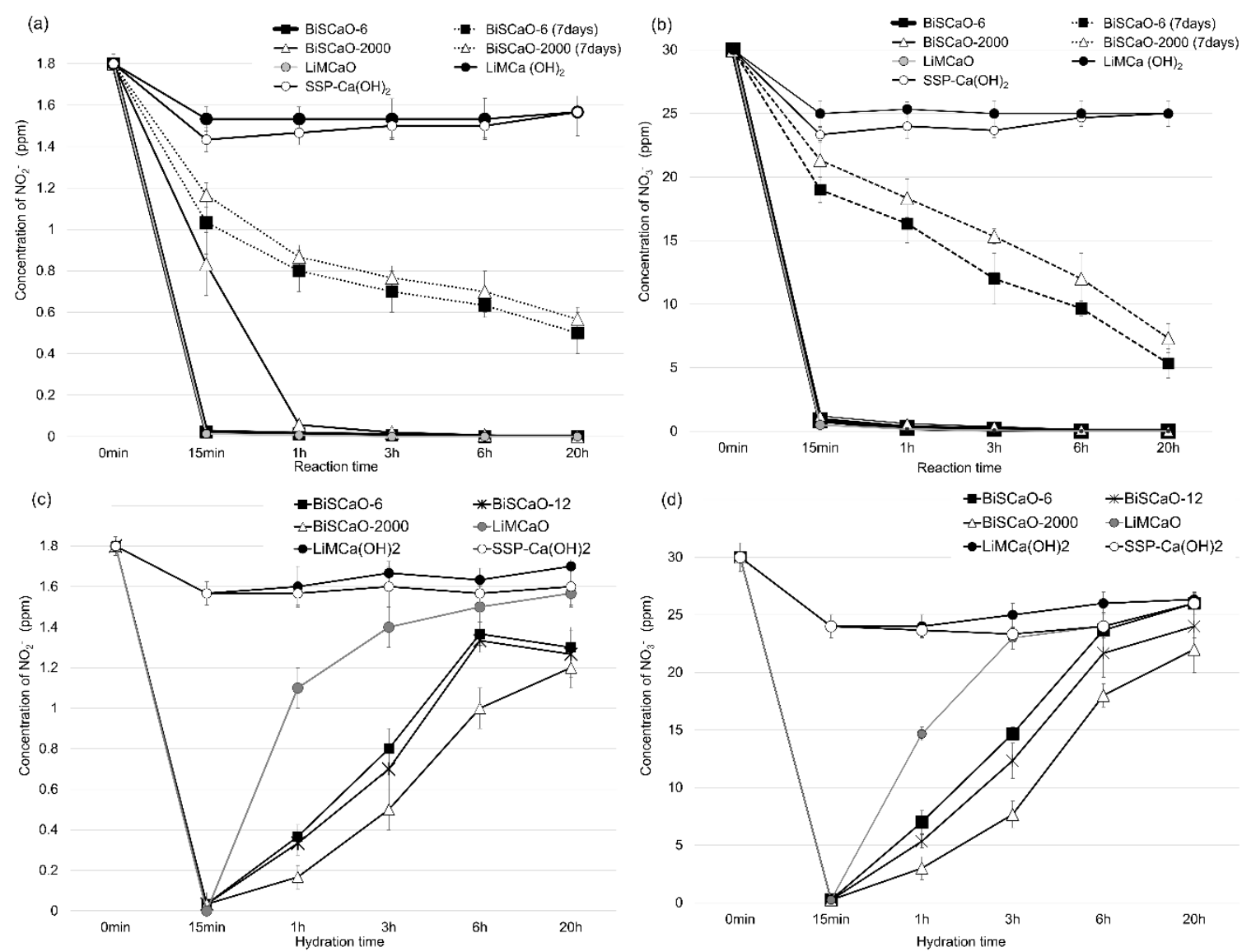

Figure 6. Decreasing $\mathrm{NO}_{3}{ }^{-}$and $\mathrm{NO}_{2}{ }^{-}$by $\mathrm{BiSCaO}, \mathrm{SSP}-\mathrm{Ca}(\mathrm{OH})_{2}, \mathrm{LiMCaO}$, and $\mathrm{LiMCa}(\mathrm{OH})_{2}$. $(\mathbf{a}, \mathbf{b})$ The concentration of $\mathrm{NO}_{3}{ }^{-}$and $\mathrm{NO}_{2}{ }^{-}$at the indicated reaction times after adding $0.2 \mathrm{wt} \%$ $\mathrm{BiSCaO}-6, \mathrm{BiSCaO}-2000$ or $\mathrm{LiMCaO}$ powders to pure water containing $1.8 \mathrm{ppm} \mathrm{NO}_{2}{ }^{-}$and $30 \mathrm{ppm}$ $\mathrm{NO}_{3}{ }^{-}$were measured. BiSCaO-6 (seven days) and $\mathrm{BiSCaO}-2000$ (seven days) were incubated at $37^{\circ} \mathrm{C}$ in the absence of desiccant for seven days before adding to pure water containing $\mathrm{NO}_{3}{ }^{-}$and $\mathrm{NO}_{2}{ }^{-}$. $(\mathbf{c}, \mathbf{d})$ Each $\mathrm{BiSCaO}$ and $\mathrm{LiMCaO}$ powder was hydrated in pure water during several time periods, then added to pure water containing $\mathrm{NO}_{3}{ }^{-}$and $\mathrm{NO}_{2}{ }^{-}$. The mixture was incubated at room temperature for $1 \mathrm{~h}$ and the concentration of $\mathrm{NO}_{3}{ }^{-}$and $\mathrm{NO}_{2}{ }^{-}$was measured.

\section{Discussion}

Some scallop shell waste is used as a calcium supplement in food and in plastering and paving materials, but most is considered industrial waste and is piled along coastlines, causing environmental problems such as offensive odors and soil pollution due to the leaching of harmful materials from the shells $[18,19,24]$. Scallop shells are mainly composed of calcium carbonate $\left(\mathrm{CaCO}_{3}\right)$, which is converted to calcium oxide (CaO) when heated above $1000{ }^{\circ} \mathrm{C}$. Heated shell powder (SSP) exhibits broad antimicrobial action against viruses, bacteria, spores, and fungi $[18,19,24]$.

Slurries of SSP nanoparticles (particle diameter range: $60-900 \mathrm{~nm}$ ) are prepared by grinding shells heated above $1000^{\circ} \mathrm{C}$ using a wet bead-grinding mill [19] and suspending the powder in sterile saline. The main component of this heated-SSP nanoparticle slurry is calcium hydroxide $\left(\mathrm{Ca}(\mathrm{OH})_{2}\right)$. Most commercially available heated-SSP products used as food additives are composed of $\mathrm{Ca}(\mathrm{OH})_{2}$ $(>90 \%)$ and not $\mathrm{CaO}(<5 \%)$. BiSCaO (Plus Lab Co. Ltd., Kanagawa, Japan) used in this study is commercially available and is prepared by heating at $1450{ }^{\circ} \mathrm{C}$ for $4 \mathrm{~h}$, then by grinding using a dry super grinder (Nano Jetmizer NJ-300-D, Aishin Nano Technologies Co. Ltd., Saitama, Japan), followed by cooling in a vacuum chamber and vacuum packing. BiSCaO comprises over $99.6 \% \mathrm{CaO}$, the average particle diameter is about $6 \mu \mathrm{m}$, and its positive zeta-potential indicates that it is a uniform and fine powder. 
Both BiSCaO and SSP-Ca(OH $)_{2}$ are poorly water-soluble under alkaline conditions. The generated precipitates in suspensions of high concentrations of $\mathrm{BiSCaO}$ and SSP-Ca $(\mathrm{OH})_{2}$ can result in a significant loss of $\mathrm{CaO}$ and the plugging of spray nozzles. A methodology is therefore needed to prepare $\mathrm{BiSCaO}$ and SSP-Ca $(\mathrm{OH})_{2}$ dispersions without precipitates. We compared several phosphate compounds such as $\mathrm{H}_{3} \mathrm{PO}_{4}, \mathrm{Na}_{3} \mathrm{PO}_{4}, \mathrm{Na}_{2} \mathrm{HPO}_{4}$, or $\mathrm{NaH}_{2} \mathrm{PO}_{4}$ as an additive for dispersions. We found some conditions for dispersion which were maintained for at least one week. For the following experiments to study the deodorization and microbicidal efficacy of $\mathrm{BiSCaO}$ dispersion, we chose $\mathrm{Na}_{2} \mathrm{HPO}_{4}$ as an additive to form dispersion because of the generation of smaller particles in dispersion, and set the weight ratio of $\mathrm{Na}_{2} \mathrm{HPO}_{4}$ to $\mathrm{BiSCaO}$ as $60 \%$. CaO particles in $\mathrm{BiSCaO}$ dispersion were nano scales with $100-300 \mathrm{~nm}$.

We examined deodorizing and bactericidal activity of $\mathrm{BiSCaO}$ dispersion under conditions such as the type of $\mathrm{BiSCaO}$ (difference in particle size), concentration, and time from preparation of the dispersion to testing. Dispersion with smaller particle (BiSCaO-6), higher concentration, and immediately after adjustment showed highest deodorization and microbicidal activities against both TC and CF. BiSCaO-6 with smaller size has higher BET specific surface area $\left(2.3 \mathrm{~m}^{2} / \mathrm{g}\right)$ than that of BiSCaO-2000 $\left(0.8 \mathrm{~m}^{2} / \mathrm{g}\right)$ (data is not shown). It was expected that the difference of BET specific surface area of BiSCaO- 6 and BiSCaO-2000 influenced deodorizing and microbicidal activities. BiSCaO-6 dispersion with immediately after adjustment showed higher deodorization and microbicidal activities than $\mathrm{SSP}-\mathrm{Ca}(\mathrm{OH})_{2}$ dispersion with immediately after adjustment. Furthermore, BiSCaO-6 dispersion with three days after adjustment decreased their activities to the same level of SSP-Ca $(\mathrm{OH})_{2}$ dispersion immediately after adjustment. These results suggested that $\mathrm{CaO}$ in dispersion has higher activities than $\mathrm{Ca}(\mathrm{OH})_{2}$ and $\mathrm{CaO}$ in dispersion was gradually hydrated with water and changed to $\mathrm{Ca}(\mathrm{OH})_{2}$ with decreasing deodorizing and microbicidal activities. Interestingly, BiSCaO-6 dispersion immediately and one day after adjustment showed higher deodorizing activities than $\mathrm{BiSCaO}$ suspension just after adjustment. This suggests that additive $\mathrm{Na}_{2} \mathrm{HPO}_{4}$ contributed the inhibition of hydration reaction from $\mathrm{CaO}$ to $\mathrm{Ca}(\mathrm{OH})_{2}$. The deodorization activity in this study considered to be derived a bactericidal activity to increased bacteria. However, a study showed that heated shell powders reduced formaldehyde [28], and the possibility of degradation activity of odorous components should be studied.

This study showed that $\mathrm{BiSCaO}$ and $\mathrm{LiMCaO}$, but not SSP-Ca $(\mathrm{OH})_{2}$ and $\mathrm{LiMCa}(\mathrm{OH})_{2}$, could reduce the concentration of $\mathrm{NO}_{2}{ }^{-}$and $\mathrm{NO}_{3}{ }^{-}$by more than $90 \%$ at room temperature within $15 \mathrm{~min}$. These results suggest that $\mathrm{CaO}$ has reducing activity against both $\mathrm{NO}_{2}{ }^{-}$and $\mathrm{NO}_{3}{ }^{-}$. The ability of $\mathrm{BiSCaO}$ and $\mathrm{LiMCaO}$ to reduce the concentration of both $\mathrm{NO}_{2}$ - and $\mathrm{NO}_{3}$ - decreased as the period of hydration with $\mathrm{NO}_{2}{ }^{-} / \mathrm{NO}_{3}{ }^{-}$samples increased. However, the speed of decreasing activity with hydration of $\mathrm{LiMCaO}$ was faster than that of $\mathrm{BiSCaO}$. These results suggested that as $\mathrm{CaO}$ was changed to $\mathrm{Ca}(\mathrm{OH})_{2}$ by hydration, the reducing activity of $\mathrm{CaO}$ decreased, and that $\mathrm{BiSCaO}$ was more stable than $\mathrm{LiMCaO}$. In addition, when $\mathrm{LiMCaO}(20 \mathrm{wt} \%)$ was added to water and mixed, the suspension boiled $\left(\geq 100^{\circ} \mathrm{C}\right)$ within $0.5-5 \mathrm{~min}$ due to the heat of hydration of the reaction between $\mathrm{CaO}$ and water. In contrast, mixing $\mathrm{BiSCaO}$ with water resulted in a gradual and controlled increase in temperature $\left(\leq 60{ }^{\circ} \mathrm{C}\right.$ ) over $10-80 \mathrm{~min}$ (data not shown). Thus, the heat generation of $\mathrm{CaO}$ in $\mathrm{BiSCaO}$ and $\mathrm{LiMCaO}$ may be correlated with a reducing effect. At any rate, further studies on the reducing effects of $\mathrm{CaO}$ molecules are required to make the mechanism clear.

$\mathrm{CaO}$ hydration generates a strong base and is the primary mechanism for the deodorization and microbicidal activities of $\mathrm{BiSCaO}$ dispersion. The $\mathrm{CaO}$ content of $\mathrm{BiSCaO}$ is much higher than that of $\mathrm{SSP}-\mathrm{Ca}(\mathrm{OH})_{2}$, and this suggested that $\mathrm{BiSCaO}$ dispersion showed higher deodorizing and microbicidal activities than SSP-Ca(OH $)_{2}$ because of the higher $\mathrm{pH}$. However, our preliminary study showed that BiSCaO-6 exhibited higher activity than $\mathrm{NaOH}$ solution at the same $\mathrm{pH}$ (data not shown). This suggests that alkalinity alone is not responsible for the deodorizing and microbicidal property of BiSCaO. We found the possibility of a reducing activity of $\mathrm{CaO}$ with $\mathrm{BiSCaO}$. Therefore, another possibility for the high disinfection activity of $\mathrm{BiSCaO}$ is that the $\mathrm{OH}^{-}$concentration of the thin water layer formed around $\mathrm{BiSCaO}$ particles might be higher than in the bulk solvent $[12,18]$. Furthermore, it has been proposed that active radical species generated from $\mathrm{MgO}$ or $\mathrm{CaO}$ may also contribute to the stronger 
disinfection activity [12,18], as supported by a multi-parameter flow cytometry study conducted by Hewitt et al. [29]. Although high $\mathrm{pH}$ is certainly the main contributor to the deodorizing and microbicidal activity of $\mathrm{BiSCaO}$, active radical species generated from $\mathrm{BiSCaO}$ may be an alternative microbicidal factor. The active radical species produced by $\mathrm{MgO}$ or $\mathrm{CaO}$ is poorly understood at present. Krishnamoorthy et al. [30] investigated the antibacterial activity of $\mathrm{MgO}$, which, like CaO, is an alkaline earth metal oxide. They suggested that the anti-bacterial activity of $\mathrm{MgO}$ relies on the presence of defects or oxygen vacancies at the surface of the particles. Since $\mathrm{MgO}$ is easily hydrated and forms a surface layer of $\mathrm{Mg}(\mathrm{OH}) 2$, it readily establishes surface-bound electron-hole pairs that can decompose into a surface-trapped electron and a localized hole state [31,32]. Further studies are required to understand the mechanism by which $\mathrm{CaO}$ exerts its microbicidal effects.

\section{Materials and Methods}

\subsection{BiSCaO and LiMCaO Powders}

Thorough cleaning scallop shell powders heated at $1450{ }^{\circ} \mathrm{C}$ for $2-6 \mathrm{~h}$, and were natural cooling. The powders were pulverized by Nano Jetmizer (NJ-300-D, Aishin Nano Technologies Co. Ltd., Saitama, Japan) to produce BiSCaO-6. BiSCaO-6 (seven days) was prepared by placing BiSCaO-6 under high humidity at $37^{\circ} \mathrm{C}$ for seven days. To prepare BiSCaO-2000, the cleaning scallop shells were baked at $1100{ }^{\circ} \mathrm{C}$ for $4 \mathrm{~h}$, and subjected to natural cooling. The powders were pulverized by general-purpose rotor crusher (IMP-400, Seishin Enterprise Co. Ltd., Tokyo, Japan).

Table 4 showed the characterization of scallop shell powders we used in this study. BiSCaO had dry powder diameters of 3-9 (average 6.2) $\mu \mathrm{m}$ in BiSCaO-6, 2-7 (average 5.3) $\mu \mathrm{m}$ in BiSCaO-6 (seven days), and 200-2000 (average 500) $\mu \mathrm{m}$ in BiSCaO-2000 and were obtained from Plus Lab Corp., Kanagawa, Japan. SSP-Ca $(\mathrm{OH})_{2}$ (Scallow) obtained from Kohkin Inst. Co. Ltd., Tochigi, Japan are dry powder diameter of 10-100 $\mu \mathrm{m}$ (average $46 \mu \mathrm{m}$ ). LiMCaO and $\mathrm{LiMCa}(\mathrm{OH})_{2}$ derived from limestone were purchased from FUJI FILM Wako Pure Chemical Corp., Osaka, Japan.

Average diameter of each dry powder ware determined using a particle size distribution measuring device (CILAS; Aishin-Nanotech Corp. Saitama, Japan). Average diameter and zeta potential of each particles in suspension or dispersion were determined using ELSZ-1000 (Otsuka Electronics Co. Ltd., Osaka, Japan). The contents of $\mathrm{CaO}$ and $\mathrm{Ca}(\mathrm{OH})_{2}$ in BiSCaO-6 and SSP-Ca $(\mathrm{OH})_{2}$ were determined using an X-ray diffractometer system (Phillips X'Pert-PRO; Phillips Japan, Ltd. Japan) performed by the Kanagawa Institute of Industrial Science and Technology (Figure 7).

Table 4. Characterization of $\mathrm{BiSCaO}, \mathrm{SSP}-\mathrm{Ca}(\mathrm{OH}) 2, \mathrm{LiMCaO}$, and $\mathrm{LiMCa}(\mathrm{OH}) 2$ used in this study.

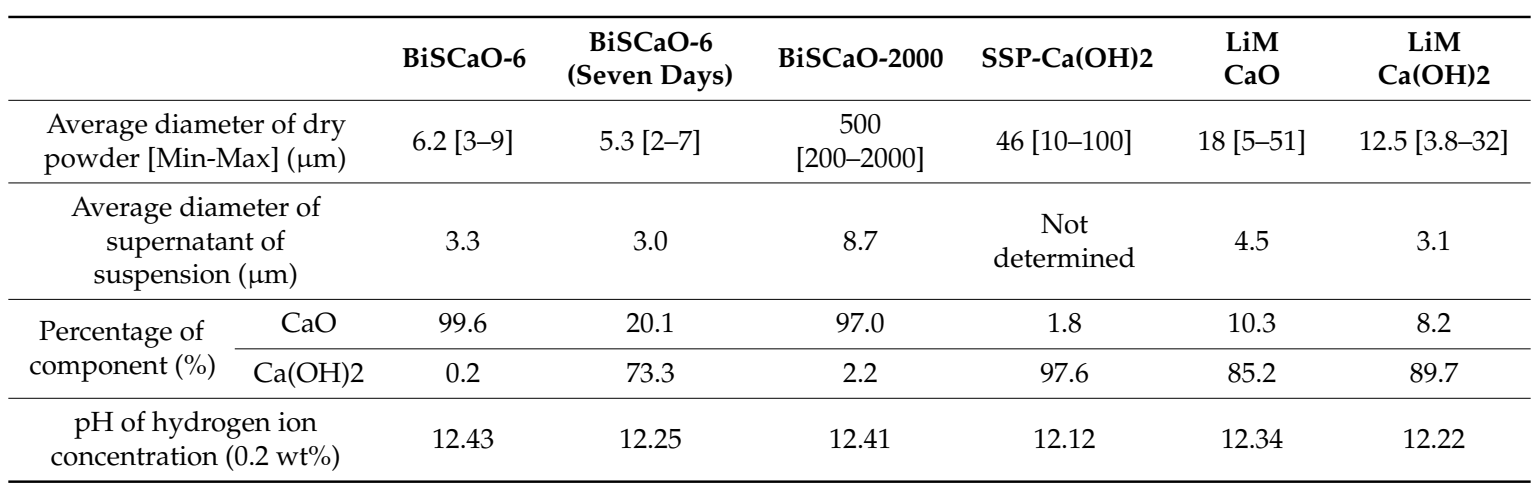



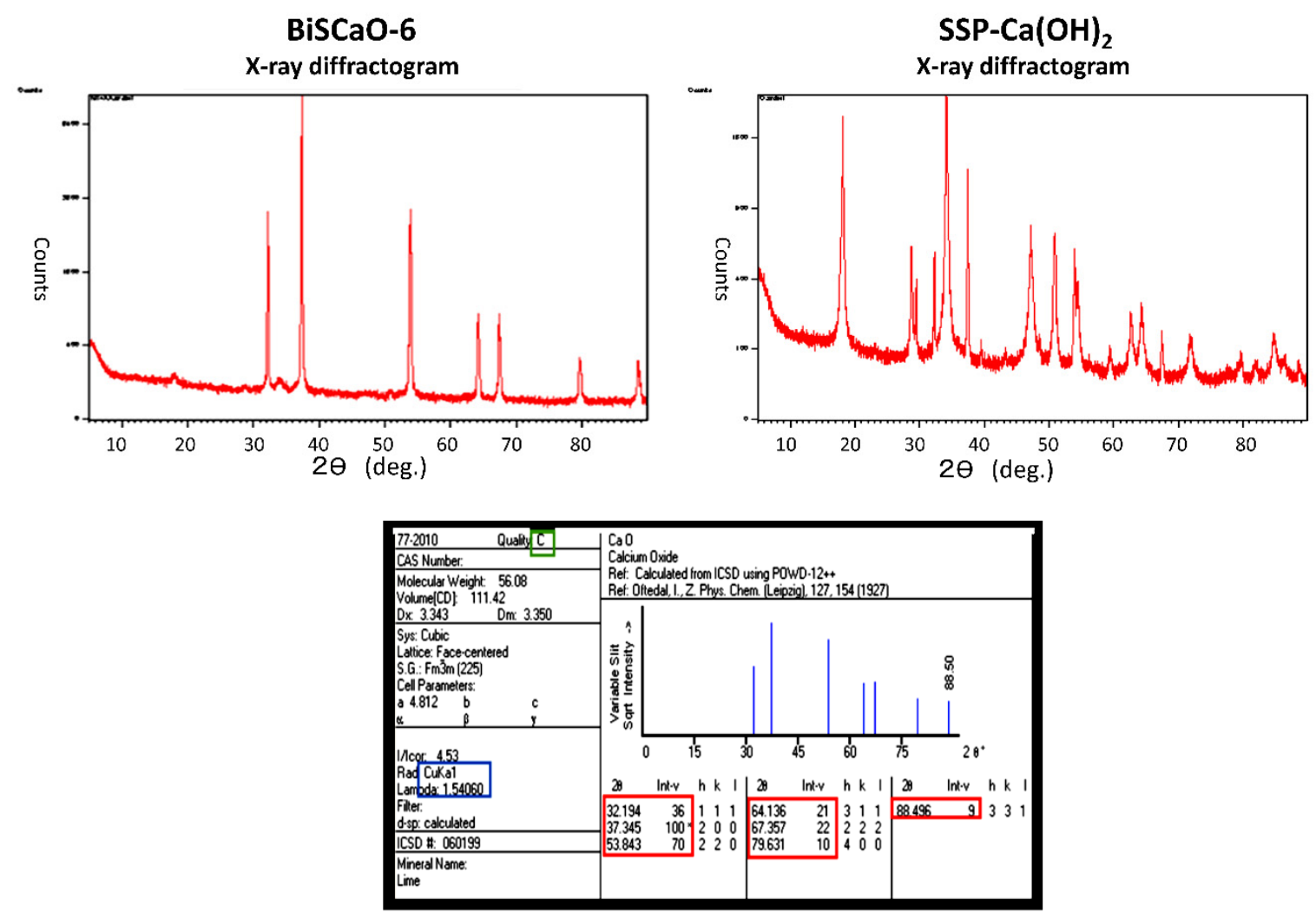

Figure 7. The contents of $\mathrm{CaO}$ and $\mathrm{Ca}(\mathrm{OH})_{2}$ in BiSCaO- 6 and SSP-Ca $(\mathrm{OH})_{2}$ were determined using X-ray diffractogram Contents of $\mathrm{CaO}$ in BiSCaO- 6 and SSP-Ca $(\mathrm{OH})_{2}$ was estimated $99.6 \%$ and $<10 \%$, respectively.

\subsection{BiSCaO Water Suspensions and Dispersions with $\mathrm{H}_{3} \mathrm{PO}_{4}, \mathrm{Na}_{3} \mathrm{PO}_{4}, \mathrm{Na}_{2} \mathrm{HPO}_{4}$ or $\mathrm{NaH}_{2} \mathrm{PO}_{4}$}

Addition to $0.2 \mathrm{~g} \mathrm{BiSCaO}-6$ to $100 \mathrm{~mL}$ of pure water, followed by rotary mixing, generated $0.2 \mathrm{wt} \%$ BiSCaO-6 suspensions. First, various amounts of phosphoric acid $\left(\mathrm{H}_{3} \mathrm{PO}_{4}\right)$, hydrochloric acid $(\mathrm{HCl})$ or sulfuric acid $\left(\mathrm{H}_{2} \mathrm{SO}_{4}\right)$ were added to $0.2 \mathrm{wt} \%$ BiSCaO-6 suspensions to adjust the $\mathrm{pH}$ to around 6, 7, $8,9,10.5,12$, and 12.5. After the measurement of $\mathrm{pH}$ with a $\mathrm{pH}$ meter (F-70, HORIBA Ltd., Kyoto, Japan), the form and the proportion of dispersion or flocculation to total amount were observed. Next, $0.04 \mathrm{wt} \%, 0.12 \mathrm{wt} \%, 0.2 \mathrm{wt} \%$, and $0.28 \mathrm{wt} \%$ of $\mathrm{Na}_{3} \mathrm{PO}_{4}, \mathrm{Na}_{2} \mathrm{HPO}_{4}$, or $\mathrm{NaH}_{2} \mathrm{PO}_{4}$ (FUJI FILM Wako Pure Chemical Corp.) were added to $0.2 \mathrm{wt} \%$ BisCaO- 6 water suspension, rotary mixed, a7nd then evaluated for $\mathrm{pH}$, form, and the proportion of layer separation with flocculation to the total amount.

\subsection{Nanoparticles in BiSCaO Dispersions Formed Using $\mathrm{H}_{3} \mathrm{PO}_{4}, \mathrm{Na}_{3} \mathrm{PO}_{4}, \mathrm{Na}_{2} \mathrm{HPO}_{4}$ or $\mathrm{NaH}_{2} \mathrm{PO}_{4}$}

Each $0.2 \mathrm{~g}$ of $\mathrm{BiSCaO}-6, \mathrm{BiSCaO}-2000$ or SSP-Ca $(\mathrm{OH})_{2}$ to $100 \mathrm{~mL}$ of pure water, followed by rotary mixing, generated $0.2 \mathrm{wt} \%$ each water suspension. Then, $0.12 \mathrm{wt} \% \mathrm{Na}_{3} \mathrm{PO}_{4}, \mathrm{Na}_{2} \mathrm{HPO}_{4}$, or $\mathrm{NaH}_{2} \mathrm{PO}_{4}$ was added to each suspension. The amount of $\mathrm{H}_{3} \mathrm{PO}_{4}$ were adjusted to be around $\mathrm{pH} 12$. After rotary mixing, $\mathrm{pH}$, average diameter, zeta potential, and form of each suspension were evaluated. Average diameter and zeta potential of particles were measured by ELSZ-1000 (Otsuka Electronics Co. Ltd., Osaka, Japan) [33,34].

For scanning electron microscope (SEM) images of dry powder, after osmium metal coating using a neo-osmium coater (Neoc-STB; Meiwafosis Co., Ltd., Tokyo, Japan), the surface structure of each dry powder was observed with SEM images of a field-resolved scanning electron microscope (JSM-6340F; JEOL Ltd., Tokyo, Japan). For cryo-SEM, samples were frozen in liquid nitrogen, then knife-cut and observed in JEOL JSM 7100F SEM (JEOL Ltd., Tokyo, Japan) under vacuum conditions at minus 90 degrees. The accelerating voltage was $10 \mathrm{KV}$, and the detection signal was a backscattered electron image. 


\subsection{Deodorization Activity of BiSCaO Dispersions}

Added to $100 \mathrm{~mL}$ of pure water, $0.04 \mathrm{~g}, 0.2 \mathrm{~g}$, and $1 \mathrm{~g}$ of BiSCaO-6, BiSCaO-2000, or SSP-Ca $(\mathrm{OH})_{2}$, followed by rotary mixing, generated $0.04 \mathrm{wt} \%, 0.2 \mathrm{wt} \%$, and $1.0 \mathrm{wt} \%$ for each water suspension. These water suspensions just after mixing were labeled as BiSCaO-6/0 suspension, BisCaO-2000/0 suspension, and SSP-Ca $(\mathrm{OH})_{2} / 0$ suspension. BisCaO-6/0, $\mathrm{BiSCaO}-2000 / 0$ and $\mathrm{SSP}-\mathrm{Ca}(\mathrm{OH})_{2} / 0$ dispersions were prepared by rotary mixing $\mathrm{Na}_{2} \mathrm{HPO}_{4}$ in each water suspension. The ratio of $\mathrm{Na}_{2} \mathrm{HPO}_{4}$ to $\mathrm{BiSCaO}$ and SSP-Ca $(\mathrm{OH})_{2}$ was $60 \%$. Each water suspension or dispersion tested one day or three days after preparation were labeled as $\mathrm{BiSCaO}-6 / 1$ suspension and $\mathrm{BiSCaO}-6 / 3$ dispersion. Five grams of tainted pork meat was mixed with $10 \mathrm{~mL}$ of each water suspension or dispersion, then placed on Petri dishes and sealed in plastic bags $(7 \times 10 \mathrm{~cm})$ for $1 \mathrm{~h}$. The odor intensity was then measured using a handheld odor meter (OMX-SRM, Shinyei Technology Co. Ltd., Hyogo, Japan).

\subsection{Microbicidal Efficacy of BiSCaO-Dispersions}

To $100 \mathrm{~mL}$ of pure water, $120 \mathrm{mg}$, $40 \mathrm{mg}, 13.3 \mathrm{mg}$, and $4.4 \mathrm{mg}$ of BiSCaO-6, BiSCaO-2000, or SSP$\mathrm{Ca}(\mathrm{OH})_{2}$ were added, followed by rotary mixing for $1 \mathrm{~min}$, generating 1200, 400, 133, and $44 \mathrm{ppm}$ for each water suspension. $\mathrm{BisCaO}-6, \mathrm{BiSCaO}-2000$, and SSP- $\mathrm{Ca}(\mathrm{OH})_{2}$ dispersions were prepared by rotary mixing $\mathrm{Na}_{2} \mathrm{HPO}_{4}$ in each suspension. The ratio of $\mathrm{Na}_{2} \mathrm{HPO}_{4}$ to $\mathrm{BiSCaO}$ and $\mathrm{SSP}-\mathrm{Ca}(\mathrm{OH})_{2}$ was $60 \%$. These dispersions just after mixing were labeled as BiSCaO-6/0, BisCaO-2000/0, and SSP-Ca(OH) $2 / 0$. Each dispersion tested one day or three days after preparation were labeled as $\mathrm{BiSCaO}-6 / 1$ and $\mathrm{BiSCaO}-6 / 3$. A contaminated suspension with normal bacterial flora (total viable cells (TC) and coliform bacteria (CF)) was prepared by incubating the remaining water in a bathtub with $10 \%$ DMEM at $37^{\circ} \mathrm{C}$ for $24 \mathrm{~h}[15,24]$. Ten milliliters of each dispersion was added to $10 \mathrm{~mL}$ of the contaminated suspension, mixed well, and incubated at room temperature for $15 \mathrm{~min}$; then, the number of colony-forming units per sample was determined. To count the number of colony-forming units (CFU), aliquots ( $1 \mathrm{~mL}$ of each mixture) were gently poured into individual Petri dishes containing pre-aliquoted portions of simple and easy dry medium for TC or CF (Nissui Pharmaceutical Co., Ltd., Tokyo, Japan) [25,31], and the plates were incubated for $24 \mathrm{~h}$ in a $37^{\circ} \mathrm{C}$ incubator (Alp Co., Ltd., Tokyo, Japan).

\subsection{Reduction of Aqueous $\mathrm{NO}_{2}$ and $\mathrm{NO}_{3}$ by BiSCaO}

Regarding the evaluation of reaction time, $0.2 \mathrm{~g}$ BiSCaO-6, $\mathrm{BiSCaO}-2000$ or $\mathrm{LiMCaO}$ powder was added to $100 \mathrm{~mL}$ pure water containing $\mathrm{NO}_{2}{ }^{-}(1.8 \mathrm{ppm})$ and $\mathrm{NO}_{3}{ }^{-}(30 \mathrm{ppm})$. BiSCaO-6 and BiSCaO-2000 powders, which were incubated at $37^{\circ} \mathrm{C}$ for seven days in the absence of desiccant before adding pure water containing $\mathrm{NO}_{2}{ }^{-}$and $\mathrm{NO}_{3}{ }^{-}$, were also evaluated. The levels of $\mathrm{NO}_{3}{ }^{+}$and $\mathrm{NO}_{2}{ }^{-}$ were measured at $15 \mathrm{~min}, 1 \mathrm{~h}, 3 \mathrm{~h}, 6 \mathrm{~h}$, and $20 \mathrm{~h}$ using a Pack Test for $\mathrm{NO}_{3} / \mathrm{NO}_{3}-\mathrm{N}$ and $\mathrm{NO}_{2} / \mathrm{NO}_{2}-\mathrm{N}$ with a Digital Pack Test-Multi SP (Kyoritsu Chemical-Check Lab., Corp., Tokyo, Japan) [35]. Regarding the evaluation of hydration time, $0.4 \mathrm{mg}$ BiSCaO-6, BiSCaO-12, $\mathrm{BiSCaO}-2000, \mathrm{SSP}-\mathrm{Ca}(\mathrm{OH})_{2}, \mathrm{LiMCaO}$, and $\mathrm{LiMCa}(\mathrm{OH})_{2}$ were hydrated in $100 \mathrm{~mL}$ pure water during several time periods: $15 \mathrm{~min}, 1 \mathrm{~h}, 3 \mathrm{~h}$, $6 \mathrm{~h}$, and $20 \mathrm{~h}$. Then, those samples were added to $100 \mathrm{~mL}$ pure water, with $\mathrm{NO}_{2}{ }^{-}(3.6 \mathrm{ppm})$ and $\mathrm{NO}_{3}{ }^{-}$ (60 ppm) added to the pure water, and incubated at room temperature for $1 \mathrm{~h}$, and the concentrations of $\mathrm{NO}_{3}{ }^{-}$and $\mathrm{NO}_{2}{ }^{-}$were calculated using a Pack Test.

\section{Conclusions}

We developed a BiSCaO dispersion by mixing with phosphate compounds without any precipitation, and flocculation caused no significant loss of the $\mathrm{BiSCaO}$ powder and plugging of spray nozzles after adding phosphate compounds such as $\mathrm{Na}_{3} \mathrm{PO}_{4}, \mathrm{Na}_{2} \mathrm{HPO}_{4}$, or $\mathrm{NaH}_{2} \mathrm{PO}_{4}$ to the $\mathrm{BiSCaO}$ suspension. The hydration reaction on the surface of $\mathrm{BiSCaO}-6$ may lead to the refinement of $\mathrm{CaO}$ crystals and rift and pore formations, which may promote the production of nanoparticles from microparticles in water dispersion. 
A dispersion of $\mathrm{BiSCaO}-6$ with smaller size showed higher deodorization and microbicidal activities than $\mathrm{BiSCaO}-2000$ with a larger size, $\mathrm{SSP}-\mathrm{Ca}(\mathrm{OH})_{2}$, and $\mathrm{BiSCaO}$ suspension. Furthermore, BiSCaO, but not SSP-Ca $(\mathrm{OH})_{2}$, could reduce the concentration of $\mathrm{NO}_{2}{ }^{-}$and $\mathrm{NO}_{3}{ }^{-}$in water solution within $15 \mathrm{~min}$. These activities of $\mathrm{BiSCaO}$ might result from the high $\mathrm{pH}(>12)$ caused by $\mathrm{CaO}$ hydration and reduction activity, probably causing active radical species.

Author Contributions: Conceptualization, Y.S., M.I., S.N., K.M., M.F. and H.Y.; Data curation, Y.S., M.I., S.N., K.F., S.H., T.T., K.M., M.F. and H.Y.; Formal analysis, Y.S.; Funding acquisition, M.I., M.F. and H.Y.; Investigation, Y.S., M.I., K.F., S.N., S.H., T.T., K.M., M.F. and H.Y.; Methodology, Y.S., M.I., S.N., K.F., S.H., T.T., K.M., M.F. and H.Y.; Project administration, M.I., M.F. and H.Y.; Resources, M.I., M.F. and H.Y.; Software, Y.S., M.I., S.N., S.H., T.T., M.F. and H.Y.; Supervision, M.I., M.F. and H.Y.; Validation, Y.S., M.I., M.F. and H.Y.; Visualization, Y.S., M.I., K.F., S.H., T.T., K.M., M.F. and H.Y.; Writing—original draft, Y.S. and M.I.; Writing—review \& editing, Y.S., M.I., S.N., K.F., S.H., T.T., K.M., M.F. and H.Y.

Funding: This study was partially supported by the Ministry of Education, Culture, Sports, Science and Technology of the Government of Japan (grant No. 19K15955).

Acknowledgments: The authors thank Forte Inc. (www.forte-science.co.jp) for their English language editing services.

Conflicts of Interest: The authors declare no conflict of interest.

\section{References}

1. Singh, J.; Dutta, T.; Kim, K.-H.; Rawat, M.; Samddar, P.; Kumar, P. 'Green' synthesis of metals and their oxide nanoparticles: Applications for environmental remediation. J. Nanobiotechnol. 2018, 16, 84. [CrossRef] [PubMed]

2. Nations, S.; Wages, M.; Canas, J.E.; Maul, J.; Theodorakis, C.; Cobb, G.P. Acute effects of $\mathrm{Fe}_{2} \mathrm{O}_{3}, \mathrm{TiO}_{2}, \mathrm{ZnO}$ and $\mathrm{CuO}$ nanomaterials on xenopuslaevis. Chemosphere 2011, 83, 1053-1061. [CrossRef] [PubMed]

3. Mori, Y.; Tagawa, T.; Fujita, M.; Kuno, T.; Suzuki, S.; Matsui, T.; Ishihara, M. Simple and environmentally friendly preparation and size control of silver nanoparticles using an inhomogeneous system with silvercontaining glass powder. J. Nanopart. Res. 2011, 13, 2799-2806. [CrossRef]

4. Nguyen, V.Q.; Ishihara, M.; Kinoda, J.; Hattori, H.; Nakamura, S.; Ono, T.; Miyahira, Y.; Matsui, T. Development of antimicrobial biomaterials produced from chitin-nanofiber sheet/silver nanoparticle composites. J. Nanobiotechnol. 2014, 12, 49. [CrossRef] [PubMed]

5. Tan, J.; He, Q.; Pentz, J.T.; Peng, C.; Yang, X.; Tsai, M.-H.; Chen, Y.; Ratcliff, W.C.; Jiang, L. Copper oxide nanoparticles promote the evolution of multicellularity in yeast. Nanotoxicology 2019, 13, 597-605. [CrossRef] [PubMed]

6. Singha, P.; Workman, C.D.; Pant, J.; Hopkins, S.P.; Handa, H. Zinc-oxide nanoparticles act catalytically and synergistically with nitric oxide donors to enhance antimicrobial efficacy. J. Biomed. Mater. Res. Part A 2019, 107, 1425-1433. [CrossRef]

7. Priyanka, K.P.; Sukirtha, T.H.; Balakrishna, K.M.; Varghese, T. Microbicidal activity of $\mathrm{TiO}_{2}$ nanoparticles synthesized by sol-gel methods. IET Nanobiotechnol. 2016, 10, 81-86. [CrossRef]

8. Sawai, J.; Yoshikawa, T. Quantitative evaluation of antifungal activity of metallic oxide powders $(\mathrm{MgO}, \mathrm{CaO}$ and $\mathrm{ZnO}$ ) by an indirect conductimetric assay. J. Appl. Microbiol. 2004, 96, 803-809. [CrossRef]

9. Roy, A.; Gauri, S.S.; Bhattacharya, M.; Bhattacharya, J. Antimicrobial activity of CaO nanoparticles. J. Biomed. Nanotechnol. 2013, 9, 1570-1578. [CrossRef]

10. Faheem, M.; Khan-Sulehria, A.Q.; Mahadevan, K.M. A study on the synthesis, characterization and photocatalytic activity of $\mathrm{CaO}$ nanoparticle against some selected azo-dyes. Ind. J. Appl. Res. 2015, 5, 361-365.

11. Madhusudhana, K.; Yogendra, K.; Mahadevan, K.M. Decolorization of Coralene Dark Red 2B azo-dye using Calcium Oxide nanoparticle as an adsorbent. Int. J. Res. Chem. Environ. 2012, 2, 21-25.

12. Kubo, M.; Ohshima, Y.; Irie, F.; Kikuchi, M.; Sawai, J. Disinfection Treatment of Heated Scallop-Shell Powder on Biofilm of Escherichia coli ATCC 25922 Surrogated for E. coli O157:H7. J. Biomater. Nanobiotechnol. 2013, 4, 10-19. [CrossRef] 
13. Kinoda, J.; Ishihara, M.; Hattori, H.; Nakamura, S.; Fukuda, K.; Yokoe, H. Cytotoxicity of Silver Nanoparticle and Chitin-Nanofiber Sheet Composites Caused by Oxidative Stress. Nanomaterials 2016, 6, 189. [CrossRef] [PubMed]

14. Ishihara, M.; Nguyen, V.Q.; Mori, Y.; Nakamura, S.; Hattori, H. Adsorption of Silver Nanoparticles onto Different Surface Structures of Chitin/Chitosan and Correlations with Antimicrobial Activities. Int. J. Mol. Sci. 2015, 16, 13973-13988. [CrossRef] [PubMed]

15. Kuku, G.; Culha, M. Investigating the origins of toxic response in $\mathrm{TiO}_{2}$ nanoparticle-treated cells. Nanomaterials 2017, 7, 83. [CrossRef] [PubMed]

16. Wiercinski, F.J. Calcium, An overview-1989. Biol. Bull. 1989, 176, 195-217. [CrossRef]

17. Liu, F.J.; Chou, K.S.; Huang, Y.K. A novel method to make regenerable core-shell calcium-based sorbants. J. Environ. Manag. 2006, 79, 51-56. [CrossRef]

18. Sawai, J. Antimicrobial Characteristics of Heated Scallop Shell Powder and Its Application. Biocontrol Sci. 2011, 16, 95-102. [CrossRef]

19. Watanabe, T.; Fujimoto, R.; Sawai, J.; Kikuchi, M.; Yahata, S.; Satoh, S. Antibacterial Characteristics of Heated Scallop-Shell Nano-Particles. Biocontrol Sci. 2014, 19, 93-97. [CrossRef]

20. Thammakarn, C.; Satoh, K.; Suguro, A.; Hakim, H.; Ruenphet, S.; Takehara, K. Inactivation of Avian Influenza Virus, Newcastle Disease Virus and Goose Parvovirus Using Solution of Nano-Sized Scallop Shell Powder. J. Vet. Med. Sci. 2014, 76, 1277-1280. [CrossRef]

21. Sawai, J.; Miyoshi, H.; Kojima, H. Sporicidal kinetics of Baccillus subtilis spores by heated scallop shell powder. J. Food Prot. 2003, 66, 1482-1485. [CrossRef] [PubMed]

22. Xing, R.; Qin, Y.; Guan, X.; Liu, S.; Yu, H.; Li, P. Comparison of antifungal activities of scallop shell, oyster shell and their pyrolyzed products. Egypt. J. Aquat. Res. 2013, 39, 83-90. [CrossRef]

23. Sawai, J.; Nagasawa, K.; Kikuchi, M. ability of heated acallop-shell powder to disinfect staphylococcus aureus biofilm. Food Sci. Technol. Res. 2013, 19, 561-568. [CrossRef]

24. Shimamura, N.; Irie, F.; Yamakawa, T.; Kikuchi, M.; Sawai, J. Heated Scallop-Shell Powder Treatment for Deactivation and Removal of Listeria sp. Biofilm Formed at a Low Temperature. Biocontrol Sci. 2015, 20, 153-157. [CrossRef] [PubMed]

25. Sato, Y.; Ishihara, M.; Nakamura, S.; Fukuda, K.; Kuwabara, M.; Takayama, T.; Hiruma, S.; Murakami, K.; Fujita, M.; Yokoe, H. Comparison of various disinfectants on bactericidal activity under organic matter contaminated water. Biocontrol Sci. 2019, in press. [CrossRef]

26. Ishihara, M.; Murakami, K.; Fukuda, K.; Nakamura, S.; Kuwabara, M.; Hattori, H.; Fujita, M.; Kiyosawa, T.; Yokoe, H. Stability of Weakly Acidic Hypochlorous Acid Solution with Microbicidal Activity. Biocontrol Sci. 2017, 22, 223-227. [CrossRef]

27. Fukuda, K.; Ishihara, M.; Murakami, K.; Nakamura, S.; Sato, Y.; Kuwabara, M.; Fujita, M.; Kiyosawa, T.; Yokoe, H. Cleaning technique using high-velocity steam-air micromist jet spray. J. Med. Eng. Technol. 2017, 41, 522-528. [CrossRef] [PubMed]

28. Takada, T.; Furusaki, A.; Tanaka, Y. Formaldehyde reduction with scallop shell powders fired at high temperatures: Identification of the effective ingredient. Biomed. Mater. Eng. 2009, 19, 187-192. [PubMed]

29. Hewitt, C.J.; Bellara, S.R.; Andreani, A.; Nebe-Von-Caron, G.; McFarlane, C.M. An evaluation of the anti-bacterial action of ceramic powder slurries using multi-parameter flow cytometry. Biotechnol. Lett. 2001, 23, 667-675. [CrossRef]

30. Krishnamoorthy, K.; Manivannan, G.; Kim, S.J.; Jeyasubramanian, K.; Premanathan, M. Antibacterial activity of $\mathrm{MgO}$ nanoparticles based on lipid peroxidation by oxygen vacancy. J. Nanopart. Res. 2012, 14, 1-10. [CrossRef]

31. Berger, T.; Sterrer, M.; Stankic, S.; Bernardi, J.; Diwald, O.; Knözinger, E. Trapping of photogenerated charges in oxide nanoparticles. Mater. Sci. Eng. C 2005, 25, 664-668. [CrossRef]

32. Sterrer, M.; Diwald, O.; Knözinger, E. Vacancies and Electron Deficient Surface Anions on the Surface of MgO Nanoparticles. J. Phys. Chem. B 2000, 104, 3601-3607. [CrossRef]

33. Bae, H.; Ahmad, T.; Rhee, I.; Chang, Y.; Jin, S.U.; Hong, S. Carbon-coated iron oxide nanoparticles as contrast agents in magnetic resonance imaging. Nanoscale Res. Lett. 2012, 5, 44. [CrossRef] [PubMed] 
34. Kim, K.M.; Choi, M.H.; Lee, J.K.; Jeong, J.; Kim, Y.R.; Kim, M.K.; Paek, S.M.; Oh, J.M. Physicochemical properties of surface charge-modified $\mathrm{ZnO}$ nanoparticles with different particle sizes. Int. J. Nanomed. 2014, 9, 41-56.

35. Sato, Y.; Ishihara, M.; Fukuda, K.; Nakamura, S.; Murakami, K.; Fujita, M.; Yokoe, H. Behavior of nitrate nitorogen and nitrite nitrogen in drinking waters. Biocontrol Sci. 2018, 23, 139-143. [CrossRef] [PubMed] 